\title{
Using Emotional Core Therapy to Treat Addictions
}

\author{
Robert A Moylan* \\ Private Practice, USA
}

Submission: June 13, 2017; Published: June 21, 2017

*Corresponding author: Robert A. Moylan, Private Practice, Naperville, Illinois, USA, Tel: 630-788-1100; Email: bmoylan111@gmail.com

\section{Short Communication}

I am excited to help those who are fighting the war on illicit drugs and addictions. Never give up hope on those afflicted with addiction as the psychology and medical communities are working hard to improve care and provide meaningful support. Now, with the invention of Emotional Core Therapy, we have a psychological approach that is scientifically proven to be the most effective worldwide to treat addictions. What is the difference between Emotional Core Therapy (ECT) and all the other psychological approaches? ECT treats the root cause of addiction so the chances of recidivism or relapse are lessened. What is the root cause of addiction and stress? The root cause of all psychological stress is the temporary arousal of one of the four true emotions (Joy grief, fear, and relief). Often times, addicts feel that doing drugs will bring them joy when ultimately; drugs bring you grief and fear. From the time we are born, till the time we die, the four emotions serve as a navigation tool in life. The

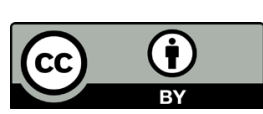

This work is licensed under Creative Commons Attribution 4.0 License DOI: 10.19080/GJARM.2017.02.555581 key for healthy individuals is to learn from these four emotions. Embrace the four emotions and really try hard to examine your relationship choices. Now, with the eight step Emotional Core Therapy flowchart, addicts and people suffering stress can have free, easy access to a proven remedy. Anyone can access for free, the Emotional Core Therapy books and training videos by going to the blog on Mr. Moylan's website at HYPERLINK "http:// www.emotionalcoretherapy.com"www.emotionalcoretherapy. com and HYPERLINK "http://www.robertmoylanlcpc.blogspot. com"www.robertmoylanlcpc.blogspot.com. To review a detailed examination of Emotional Core Therapy, please review the Journal article in this month's Global Journal of Addiction and Rehabilitative Medicine below. Which includes easy to tips to learn ECT

https://juniperpublishers.com/gjarm/pdf/GJARM. MS.ID.555576.pdf

\section{Your next submission with Juniper Publishers will reach you the below assets}

- Quality Editorial service

- Swift Peer Review

- Reprints availability

- E-prints Service

- Manuscript Podcast for convenient understanding

- Global attainment for your research

- Manuscript accessibility in different formats

( Pdf, E-pub, Full Text, Audio)

- Unceasing customer service

Track the below URL for one-step submission https://juniperpublishers.com/online-submission.php 